\title{
Pengembangan Program Pembelajaran Tematik Berbasis Nilai-Nilai Keislaman untuk TK/RA
}

\author{
Miratul Hayati ${ }^{1}$ \\ Pendidikan Islam Anak Usia Dini, Universitas Agama Islam Negeri Syarif Hidayatullah \\ Jakarta
}

DOI: $\underline{10.31004 / \text { obsesi.v6i1.938 }}$

\begin{abstract}
Abstrak
Program pengembangan pembelajaran tematik berbasis nilai-nilai keislaman bertujuan sebagai pijakan pengembangan pelaksanaan pembelajaran di sekolah, khususnya di TK Islam dan Raudhathul Athfal. Model penelitian yang digunakan adalah Research and Development $(\mathrm{RnD})$ model Borg and Gall yang dipadukan dengan model instruksional Dick and Carey. Langkah penelitian mengacu kepada upaya pengembangan: identifikasi tujuan pembelajaran (2) melakukan analisis materi ajar (3) melakukan analisis peserta didik dan konteks pembelajaran, (4) menentukan target pembelajaran (5) mengembangkan instrumen penilaian (6) mengembangkan strategi belajar (7) menyeleksi bahan ajar untuk diterapkan. Uji Coba dilakukan dengan one to one expert dan one to one guru. Hasil penelitian ini berbentuk program pembelajaran yang memuat tema-tema pembelajaran tematik yang disesuaikan dengan tahap perkembangan dan kebutuhan belajar anak dengan berbasis nilai-nilai keislaman.
\end{abstract}

Kata Kunci: program pembelajaran; tematik berbasis nilai-nilai keislaman

\begin{abstract}
The thematic learning development program based on Islamic values aims as a foundation for developing the implementation of learning in schools, especially in Islamic Kindergarten and Raudhathul Athfal. The research model used was the Borg and Gall's Research and Development $(R \& D)$ model combined with the Dick and Carey instructional model. The research stage refers to development efforts: identifying learning objectives (2) analyzing teaching materials (3) analyzing students and the learning context, (4) determining learning targets (5) developing assessment instruments (6) developing learning strategies (7) selecting teaching materials to apply. The trial was carried out on one to one expert and one to one teacher.The results of this study are in the form of a learning program that contains thematic learning themes that are tailored to the developmental stage and learning needs of children based on Islamic values.
\end{abstract}

Keywords: learning program; thematic based on islamic values

Copyright (c) 2021 Miratul Hayati

$\triangle$ Corresponding author :

Email Address: miratul.hayati@uinjkt.ac.id (Jakarta, Indonesia)

Received 1 December 2020, Accepted 31 December 2020, Published 3 Juni 2021 


\section{PENDAHULUAN}

Pendidikan anak usia dini adalah pendidikan pertama dan utama bagi manusia dalam kehidupan, menjadi pondasi awal bagi anak menuju kehidupan selanjutnya. Anak usia dini yang berada pada masa emas (golden age) berada pada fase berkembangnya seluruh aspek perkembangan dengan pesat baik fisik, motorik, bahasa, kognitif, sosial emosional (Daelmans et al., 2017).

Beberapa penelitian menyatakan bahwa periode ini merupakan periode yang penting, (Hurlock, 1978; Santrock, 2002; Lim \& Genishi, 2010) dan memerlukan perhatian khusus agar anak mendapatkan pengasuhan dan pembelajaran yang sesuai dengan kebutuhan perkembangannya. Anak menunjukkan kemajuan pesat dalam hal emosi, sosial, regulasi, dan kapasitas moral. Usia dini menjadi dimensi perkembangan awal yang saling terkait (Powell \& Dunn, 1990).

Delapan tahun pertama kehidupan seorang anak adalah masa pertumbuhan dan perkembangan yang luar biasa. Otak berkoneksi berlipat ganda (Britto et al., 2018) secara eksponensial dalam tiga tahun pertama, dan potensi ini terus optimal sangat tinggi sampai usia delapan tahun (Black et al., 2017). Sangat penting bahwa peluang ini sepenuhnya harus digunakan dan diperkuat untuk memastikan keberlangsungan kehidupan anak selanjutnya.

Penelitian menunjukkan bahwa PAUD bisa menjadi instrumen yang ampuh untuk membantu memutus siklus kemiskinan di banyak negara (Arnold, 2004). Karena, mampu meningkatkan pendapatan orang dewasa, dan dapat memutus siklus kemiskinan antargenerasi serta kehilangan sumber daya manusia (Daelmans et al., 2017). PAUD juga diakui secara luas sebagai jalur signifikan menuju inklusivitas dan kesetaraan sosial dalam pendidikan. Ketersediaan programnya dapat diakses oleh semua lapisan masyarakat (Miyahara dan Meyers, 2008; Becher dan Li, 2010). Anak-anak yang telah berpartisipasi dalam PAUD berkualitas tinggi menunjukkan peningkatan yang cukup besar dalam bidang sosial, pendidikan, kesehatan dan intelektual, sangat berbeda dari mereka yang tidak memiliki kesempatan untuk berpartisipasi dalam program PAUD. (Mathwasa \& Okeke, 2017)

Program demi program telah dibuat dan dievaluasi. Untuk menjamin perkembangan yang optimal bagi semua anak, maka perlu dibuat suatu perencanaan kerangka kurikulum atau program pembelajaran yang mencakup pengetahuan dan keterampilan yang sesuai perkembangan, dengan memperhatikan fleksibilitas untuk kontekstualisasi. Kerangka kurikulum dan program pembelajaran juga diperlukan untuk memastikan keterlibatan seluruh aspek perkembangan, kebutuhan perkembangan anak serta memfasilitasi pendekatan pedagogis untuk mencapai tingkat kualitas program PAUD.

Pemikir Barat seperti Rousseau, Froebel, Dewey (Cahan, 1992) dan Montessori (Thornton \& Brunton, 2014) telah menjadi pelopor dalam gerakan pendidikan anak usia dini. Dewey menekankan pada pembelajaran yang melibatkan pengalaman sehari-hari yang berasal dari naluri anak itu sendiri, kegiatan, dan minat harus menjadi titik awal pendidikan. Froebel percaya tindakan dan observasi langsung adalah cara terbaik untuk mendidik anak (Bruce, 2012). Ide mereka telah membuka wawasan untuk penerapan kegiatan sensoris dan praktis dalam membentuk isi kurikulum dan program pembelajaran. Wawasan mereka tentang pentingnya eksplorasi dan bermain, seni, ritme, sajak, gerakan, dan partisipasi aktif anak diaplikasikan dalam penyusunan kurikulum dan program pembelajaran.

Salah satu pendekatan yang digunakan dalam pembelajaran anak usia dini adalah pendekatan tematik. Pendekatan tematik disusun berdasarkan tema-tema pilihan. Keunggulan dari pendekatan ini memberikan keluasan dan kedalaman bagi anak untuk mengenal dan mempelajari suatu hal, sehingga memunculkan pembelajaran yang dinamis disamping itu memberi keluasan kepada anak untuk berksplorasi dan mengembangkan kreativitasnya, menumbuhkan rasa ingin tahu terhadap alam dan lingkungan melalui proses pencarian dan penyelidikan yang mendalam (Joni, 2009). 
Proses pembelajaran tidak hanya sekedar menghafal dan mengetahui sebuah konsep atau fakta-fakta saja, dibalik itu belajar adalah kemampuan untuk menghubungkan satu pengetahuan dengan pengetahuan lain, sehingga menghasilkan pemahaman yang sempurna tentang suatu fakta atau kejadian serta mudah dipahami. Agar pembelajaran menjadi bernilai maka tugas seorang guru adalah menggali konsep-konsep yang sudah ada di skema anak dan membantunya untuk menghubungkan dengan konsep-konsep baru dengan melibatkan indera. Dalam artian, belajar bisa menjadi efektif ketika anak melakukan eksplorasi langsung dan mengalami tentang apa yang sedang dipelajarinya sesuai dengan tahapan perkembangan dan usianya. Maka pembelajaran tema membantu anak untuk melakukan proses belajar yang lebih bermakna, karena dengan pendekatan tematik berusaha untuk memadukan beberapa pengetahuan atau fakta yang satu dengan yang lainnya sehingga dapat memberikan pengalaman bagi anak.

Kelebihannya, model tematik merupakan sebuah pendekatan yang memungkinkan anak belajar secara individual maupun kelompok secara aktif untuk menggali, mencari dan mengeksplorasi banyak hal untuk menemukan pengetahuan baru secara holistik dan autentik. Pembelajaran ini berusaha memadukan pokok bahasan dalam satu tema besar. Sehingga diharapkan anak memiliki kedalaman wawasan dan pengetahuan, sikap keterampilan yang beragam dan kompleks tidak terpecah-pecah.

Dalam konteks itu, pengembangan program pembelajaran di TK yang berbasis Islam dan RA masih monoton, belum memperhatikan perkembangan dan kebutuhan anak yang faktual serta masih belum mengembangkan nilai-nilai keislaman. Berdasarkan observasi yang dilakukan pada sebuah RA di Ciputat. Guru-guru baru sekedar melakukan duplikasi pembuatan rancangan pembelajaran mingguan, harian hingga menjadi program semester dan tahunan. Padahal, nilai-nilai keislaman perlu diperkenalkan kepada anak sejak dini, keislaman tidak hanya sebatas pada kemampuan anak dalam menghafalkan doa-doa, bacaan shalat ataupun nyanyian yang bertemakan keislaman lebih jauh lagi keislaman adalah landasan yang menjiwai aspek pendidikan dan pembelajaran terutama di tataran pendidikan anak usia dini. Masih banyak sekolah TK dan RA yang memisahkan konten keislaman menjadi satu mata pelajaran, ditambah lagi dengan kebijakan dari Subdit PAI-TK yang mengharuskan adanya mata pelajaran Pendidikan Agama Islam (PAI) di TK menjadi suatu bagian yang terpisah dari pembelajaran lainnya. Padahal tidaklah demikian, insert nilai-nilai keislaman bisa dilakukan melalui pendekatan tematik yang sudah dikembangkan oleh ahli sebelumnya.

Konten-konten pembelajaran keagamaan yang ada di TK yang berbasis Islam dan RA, terfokus kepada hafalan doa-doa dan bacaan shalat serta surat-surat pendek dalam Al-Qur' an. Kondisi ini diperkeruh dengan observasi yang dilakukan pada TK berbasis Islam dan RA, ditemukan buku-buku pedoman untuk anak dan orang tua yang bias dengan nilai-nilai kekerasan, jauh dari kesan islam yang humanis dan toleran (Penilaian Buku Kemenag, 2019). Bahkan sebuah kejadian di sebuah TK di Jawa Timur tahun 2018, sekolah tersebut mengadakan kegiatan karnaval untuk siswanya dimana anak-anak diminta untuk mengenakan cadar bagi yang perempuan dan memegang replika senjata (BBC News Indonesia, 2018). Fenomena seperti ini menjadikan kekahawatiran dalam penanaman sikap intoleran dalam beragama sejak usia dini, padahal usia dini adalah usia yang potensial untuk menanamkan ideologis-ideologi yang benar tentang sikap keberagamaan anak kelak.

Dengan berlandaskan kepada kondisi diatas, menjadi dasar, bahwa paham-paham intoleran perlu ditanggulangi dan dicegah sejak anak menanjak usia dini, karena selama ini penelitian baru terfokus kepada usaha intoleransi di tingkat sekolah dasar dan menengah (Yani \& Jazariyah, 2020), oleh karena itu perlu disusun sebuah program pembelajaran yang berbasis kepada nilai-nilai Islam yang humanis dan toleransi dimulai dari PAUD.

Nilai-nilai Islam (Islamic Values) bertujuan untuk mencetak jiwa manusia agar memiliki sikap yang benar yang teraktualisasi dalam kehidupan sehari-hari. Meningkatkan keimanan, meningkatkan pemahaman anak terhadap pendalaman dan implementasi ajaran Islam 
(Endang, 2010; Ikhwan et al., 2019). Nilai-nilai Islam menjadi pedoman dalam pembentukan nilai-nilai agama di sekolah. Nilai ini diajarkan agar peserta didik atau anak mampu mengamalkan ajaran Islam dalam kehidupan mereka (Sidiq \& Ikhwan, 2018).

Pembelajaran berbasis nilai-nilai Islam merupakan upaya mengembangkan sifat keberagaman (religiusitas) anak, agar mampu memahami, menghayati dan mengamalkan ajaran agama Islam. Dengan demikian, nilai-nilai yang ditanamkan sejak kecil akan membentuk manusia yang beriman, bertakwa kepada Tuhan, dan berakhlak mulia kepada diri mereka sendiri, keluarga dan masyarakat pada umumnya (Nasution, 2018). Membuat anak mampu beradaptasi dengan situasi sosial di lingkungannya, sehingga mampu bersosialisasi dengan orang lain dan memecahkan masalah dalam kehidupan sehari-hari, menghindari dari pengaruh negatif lingkungan yang tidak sehat dan perilaku buruk (Jasuri, 2015).

Proses internalisasi nilai-nilai agama yang diaktualisasikan di sekolah membutuhkan bantuan dan sarana dari berbagai bentuk, salah satunya memasukkan ke dalam kurikulum atau program pembelajaran. Penerapan nilai-nilai Islam di TK bisa diwujudkan dalam berbagai kegiatan tersebut seperti wudhu, kegiatan amalan shalat, zakat fitrah, dan lain-lain (Ikhwan et al., 2019).

Program pembelajaran yang baik harus menentukan tujuan yang akan dicapai. Dibutuhkan perencanaan yang jelas sehingga anak tidak diperlakukan dengan pendekatan yang tidak tepat atau bahkan pendekatan yang merugikan. Tindakan yang tidak tepat akan sangat berpengaruh pada perkembangan anak selanjutnya. Seperti yang diungkapkan Montessori, anak akan dapat mengkategorisasi persepsinya menjadi bentuk pemahaman yang nyata dan benar tentang kehidupan dan lingkungannya jika lingkungan dimana ia hidup dan berkembang dirancang dan diprogram secara benar dan tepat (Suryana, 2016).

Penelitian ini berupaya untuk menciptakan satu desain program pembelajaran tematik yang sesuai dengan perkembangan, ramah anak, dan memuat tema-tema keislaman. Sehingga TK dan RA yang diselenggarakan dapat dijalankan dengan baik dan menjadikannya sebagai taman bermain anak yang konstruktif, edukatif, dan ramah anak. Adapun penelitian ini mengangkat tema, "Pengembangan Program Pembelajaran Tematik Anak Usia Dini di Taman Kanak-Kanak dan Raudatul Atfal di Ciputat Tangerang". Kebaruan dalam penelitian ini dapat dilihat dari beberapa hal yang dideskripsikan sebagai berikut: pertama, kebaruan penelitian dilihat dari topik yang disampaikan, bahwa kajian penelitian ini memiliki fokus pada pengembangan program pembelajaran tematik berbasis keislaman di TK dan RA. Kedua, produk dari penelitian ini adalah menghasilkan sebuah program pembelajaran tematik berbasis nilai-nilai keislaman di TK dan RA yang akan digunakan dalam proses pembelajaran di sekolah.

Melalui penelitian ini diharapkan program pembelajaran di TK dan RA dapat terwujud. Penelitian ini pun diharapkan menjadi blue print pengembangan program pembelajaran tematik berbasis nilai-nilai keislaman di TK atau RA di Ciputat Timur khususnya dan di Indonesia umumnya.

\section{METODOLOGI}

Penelitian ini dilakukan untuk TK/ RA di Ciputat Tangerang Selatan. Metode yang digunakan dalam penelitian ini adalah pendekatan Reseach and Development ( $R$ \& D). R\&D merupakan penelitian dan pengembangan yang digunakan untuk mengembangkan dan memvalidasi produk-produk pembelajaran dengan prosedur dan langkah-langkah yang tersistematis (Gall et al., 1996). Penelitian dan Pengembangan dilakukan dengan memadukan model penelitian Borg and Gall dengan model Dick and Carey (Dick et al., 2005). Model Dick and Carey digunakan dalam pengembangan pembelajaran dan produk, sedangkan Borg and Gall digunakan untuk perbaikan-perbaikan model yang telah dibuat. 
DOI: $10.31004 /$ obsesi.v6i1.938

Penelitian diawali dengan mengumpulkan informasi tentang proses pembelajaran yang sedang berlangsung atau terjadi di TK/RA terkait dengan program keislamannya, informasi yang didapatkan dari observasi dan penyebaran kuesioner yang melibatkan guruguru di TK/RA. Rancangan model dalam penelitian ini adalah model fisikal berupa program pengembangan pembelajaran tematik berbasis nilai-nilai keislaman untuk TK/RA. Program pembelajaran yang dikembangkan terdiri dari (1) Penentuan tema pembelajaran (yakni tematema keislaman) (2) Menentukan Kompetensi Initi (KI) dan Kompetensi Dasar (KD) pembelajaran sesuai dengan K.13 PAUD (3) Menyusun dan merumuskan indikator pembelajaran (4) Merumuskan tujuan pembelajaran (5) Merumuskan kegiatan yang akan dilakukan dalam pembelajaran (6) Menetapkan bahan dan alat yang dibutuhkan dalam pembelajaran (7) Menjabarkan langkah-langkah pembelajaran (8) Menentukan assesmen yang digunakan. Gambaran alur model fisik pada gambar 1.

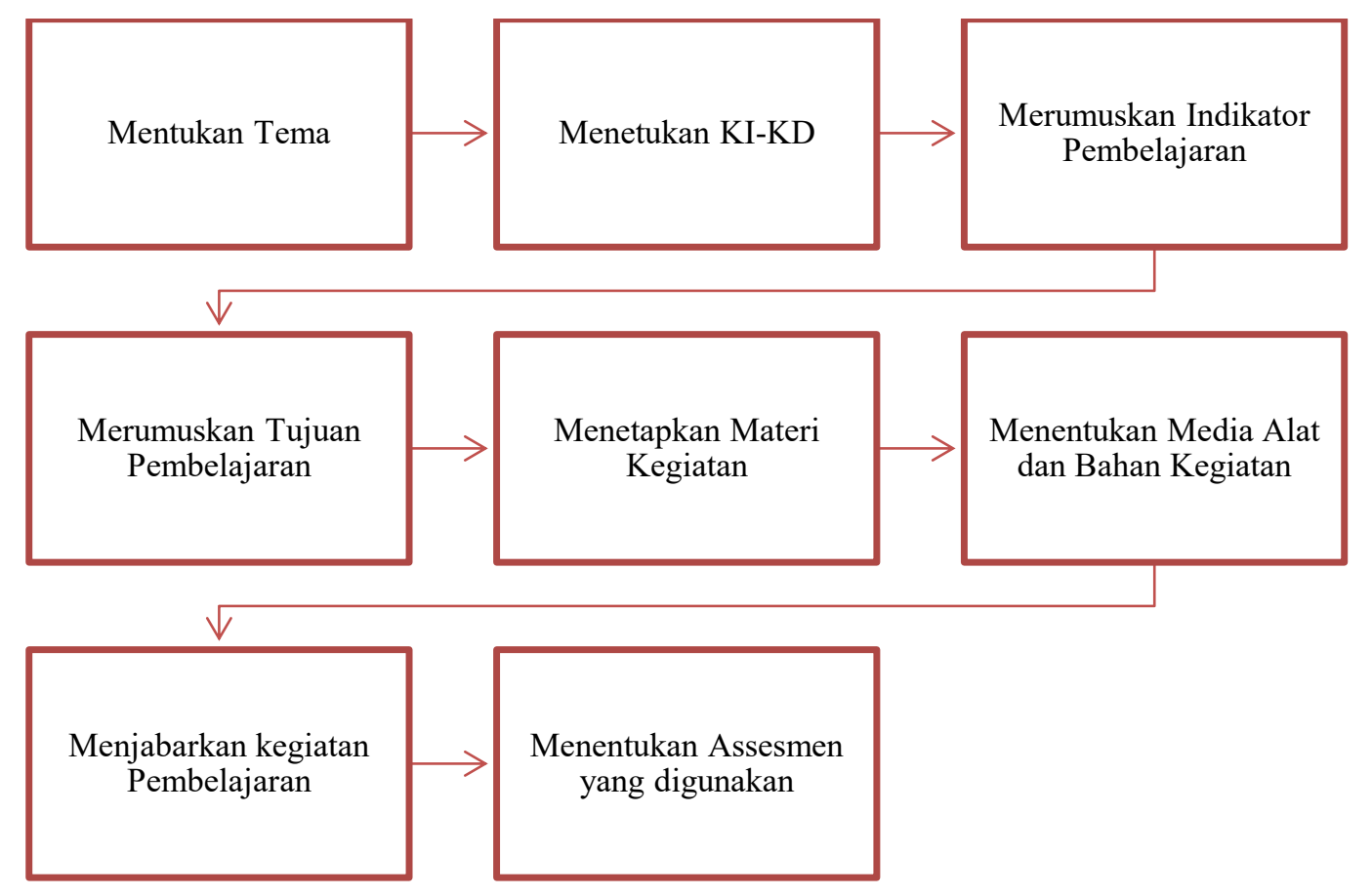

Gambar. 1. Alur Model Fisik

\section{HASIL DAN PEMBAHASAN}

Program pengembangan disusun berdasarkan sembilan tema pembelajaran yang disarikan dari Al-Quran dan Hadis sebagai berikut: (1) Aku Ciptaan Allah, (2) Shalat, (3) Birrul Walidain (4) Rumahku Surgaku (Baiti Jannati), (5) Keteladanan Nabi, (6) Jual Beli, (7) Tumbuhtumbuhan yang disebutkan dalam Al-Quran (8) Hewan yang disebutkan di dalam Al-Qur'an, (9) Alam semesta Ciptaan Allah. Semua tema pembelajaran tersebut disusun dengan sistematis dari yang sederhana sampai kepada yang komplek, dari yang dekat dengan anak, seperti; pengenalan terhadap dirinya, lingkungannya dan lingkungan di luarnya, agar guru dan anak dapat memahami dan melaksanakan kegiatan pembelajaran dengan baik serta mampu menghadirkan langkah-langkah kegiatan serta media yang tepat untuk perkembangannya.

Secara konseptual pengembangan program pembelajaran PAUD berbasis nilai-nilai keislaman dibuat dengan melakukan langkah-langkah secara bertahap untuk mencapai tujuan tertentu atau dalam menyelesaikan produk yang akan dihasilkan. Tahap pengembangan program pembelajaran tematik berbasis nilai keislaman dikembangkan dengan menggunakan desain instruksional Dick and Carey yang disederhanakan menjadi empat tahapan saja dengan langkah-langkah sebagai berikut: 


\section{Tahap Analisis Kebutuhan}

Tujuan dari tahapan ini adalah untuk menganalisis dan mengkaji tujuan dari produk yang akan dikembangkan. Produk yang akan dikembangkan adalah program pembelajaran. Pengembang melakukan kajian terhadap kurikulum yang berlaku dalam hal ini adalah Kurikulum 2013 PAUD (K.13 PAUD) agar program yang dikembangkan tetap sesuai dengan kurikulum yang berlaku secara nasional. Dari hasil analisis kurikulum akan melahirkan tematema yang disesuaikan dengan Kompetensi Inti (KI) dan Kompetensi Dasar (KD), dalam tahapan ini juga akan ditentukan program yang akan dikembangkan berupa satuan program satu semester yang bisa digunakan untuk kegiatan pembelajaran di TK/RA.

\section{Tahap Desain Produk}

Dalam mendisain program pembelajaran tematik berbasis nilai-nilai keisalaman. Pengembang mendisainnya seperti buku pedoman pembelajaran. Desain buku dilengkapi dengan cover, ilustrasi, bagan, tabel. Hal ini untuk memudahkan pengguna dalam mengimplementasikan langkah-langkah pembelajaran tematik berbasis nilai-nilai keislaman dalam pembelajaran kepada siswa TK/RA. Tahapan ini menghasilkan desain produk awal berupa buku panduan pelaksanaan program pembelajaran

\section{Tahap Validasi dan Evaluasi}

Pelaksanaan validasi dan evaluasi merupakan tahapan inti dari penelitian dan pengembangan. Tahap pra validasi dilakukan dengan mengkonsultasikannya kepada teman sejawat yang berprofesi sama untuk mendapatkan masukan awal dari pengembangan produk program pembelajaran ini. Tahapan pra-validasi bermanfaat untuk menilai layak atau tidaknya produk yang dikembangkan sebelum dinilai oleh pakar/expert. Validasi dan penilaian secara kualitatif dan kuantitatif dilakukan oleh pakar yang menghasilkan masukan untuk penyempurnaan produk yang dikembangkan. Setelah itu produk yang sudah divalidasi diujicobakan kepada calon pengguna dalam hal ini adalah siswa TK/RA.

\section{Tahap Produk Akhir}

Pada tahapan akhir akan menghasilkan produk berupa program pembelajaran tematik berbasis nilai-nilai keislaman berupa program Pembelajaran (RPPH satu semester) untuk untuk digunakan oleh guru TK/RA yang sudah melalui proses revisi berdasarkan masukan dari para pakar dan proses. Produk akhir berupa program pembelajaran siap diproduksi secara massal dan digunakan dalam proses pembelajaran di TK/RA pada gambar 2 dan Dengan model prosedural pada gambar 3. Kemudian tema tersebut dijabarkan lagi menjadi sub-tema, seperti pada gambar 4 .

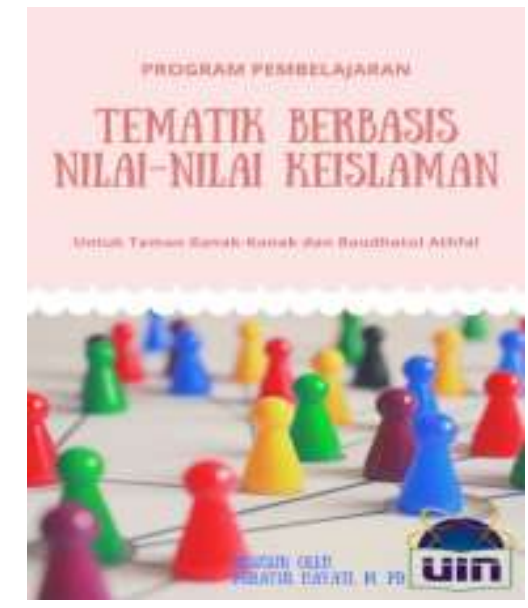

Gambar 2. Produk Akhir Pengembangan Program Pembelajaran Tematik 


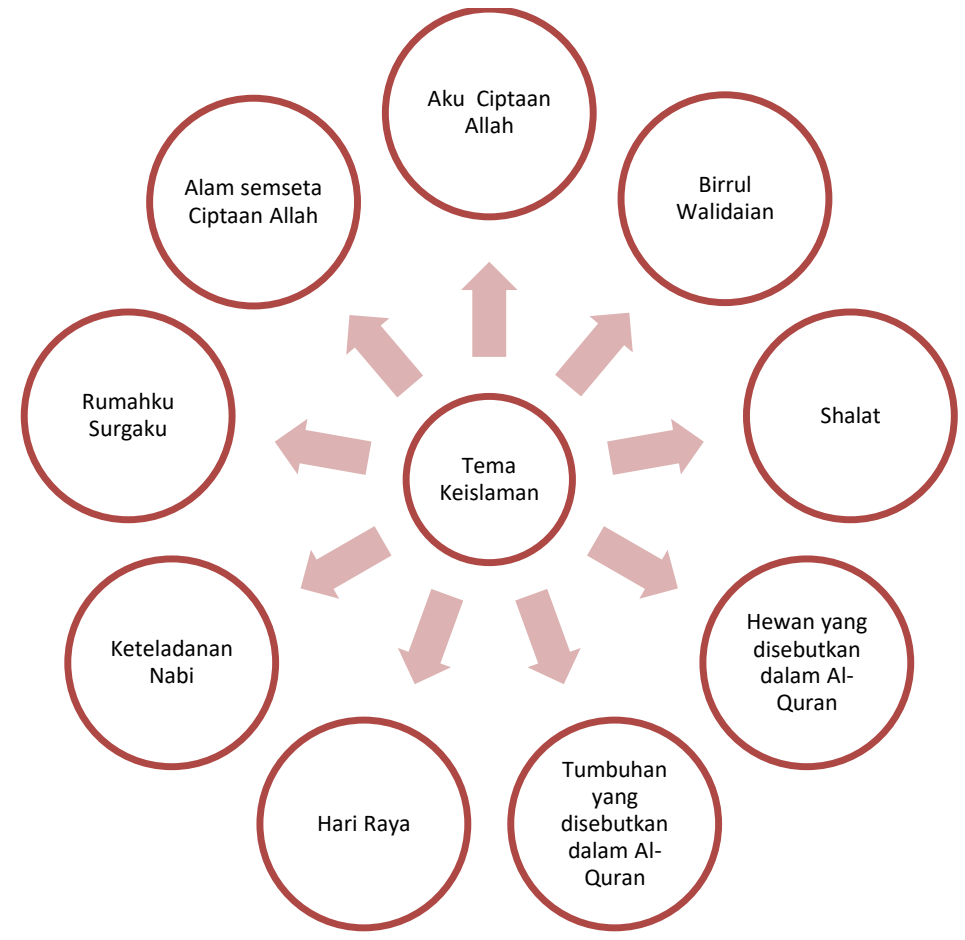

Gambar 3. Pengembangan Tema Keislaman Model Webbed
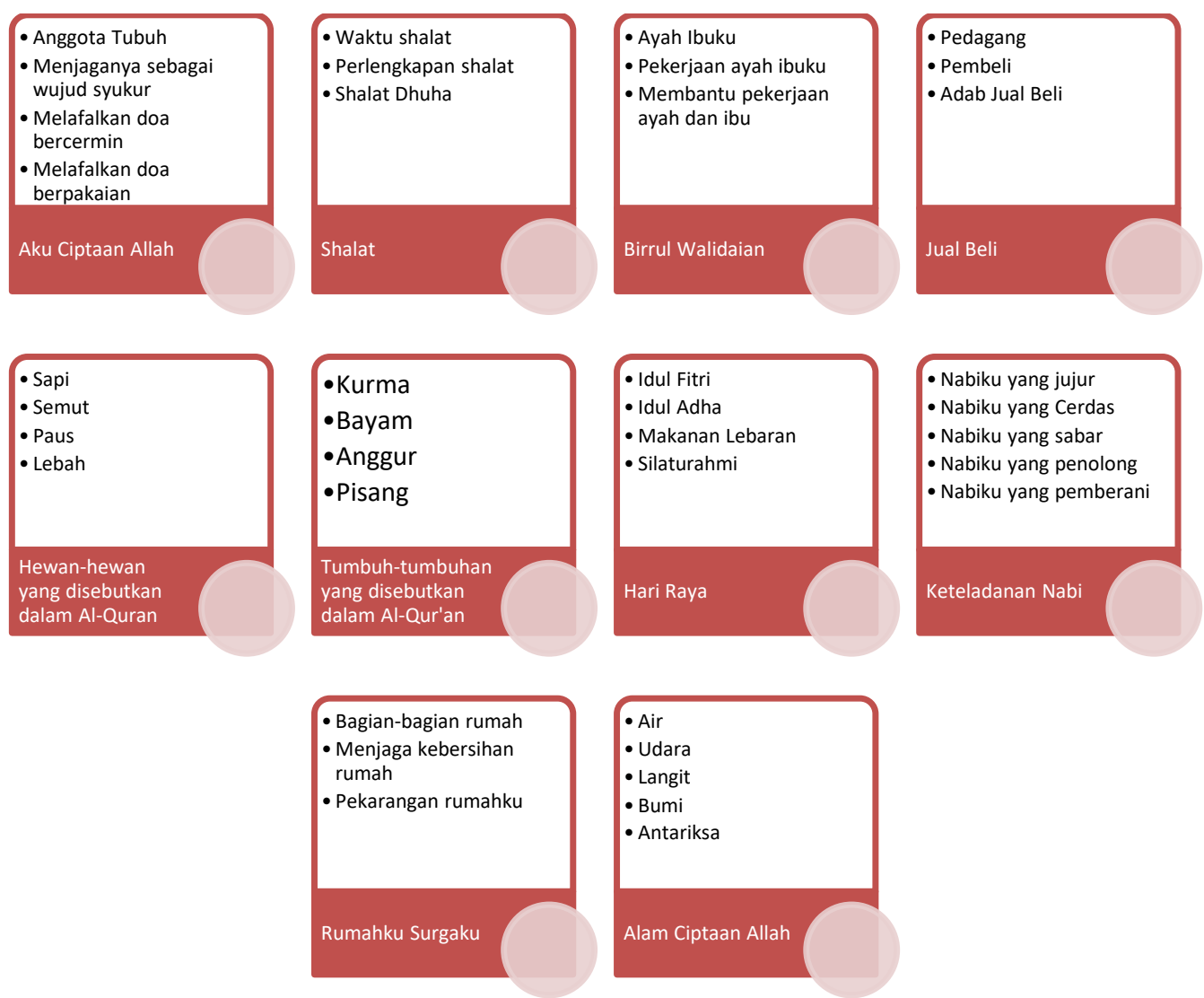

\section{Gambar 4. Pengembangan Tema-Sub-Tema berbasis Nilai-Nilai Keislaman Model Webbed}

Tema dan sub-tema yang disusun kemudian dijabarkan sesuai dengan aspek dan tingkat pembelajaran anak, sehingga terbentuk sebuah kerangka program pembelajaran yang sesuai dengan kebutuhan anak dan tidak kehilangan nilai keislamnnya. Dari program pengembangan yang telah dibuat, menjadi landasan dan acuan untuk pengembangan 
program kegiatan pembelajaran harian anak di sekolah. Adapun pengembangan program pembelajaran dikembangkan dalam bentuk Rencana Pelaksanaan Pembelajaran Harian (RPPH).

Penelitian pendahuluan berupa analisis kebutuhan dilakukan dalam pengembangan model pembelajaran berbasis nilai-nilai keislaman. Target dari pengembangan pembelajaran ini adalah agar pembelajaran yang dilaksanakan oleh guru-guru di RA dapat berjalan dengan baik dalam mengangkat nilai-nilai keislaman yang lebih luas. Analisis kebutuhan ini meliputi beberapa hal:

Pertama, pembelajaran di RA masih konvensional, dalam artian menggunakan pembelajarn dengan sistem klasikal dan monoton dalam melakukan pembelajaran sehingga guru lebih banyak aktif dan siswa cenderung hanya mengikuti arahan guru. Kedua, pembelajaran belum banyak menggunakan pendekatan yang sesuai dengan perkembangan anak. Pembelajaran masih cenderung pada hafalan dan pengembangan aspek kognitif semata, sehingga kreativitas dan inovasi anak belum menunjukkan soft skill yang menunjang kebutuhan anak pada masa yang akan datang. Ketiga, belum mengangkat tema-tema keislaman dengan terstruktur, dalam artian tema-tema keislaman yang diangkat dalam pembelajaran belum digali sesuai tingkat kebutuhan dan perkembangan anak.

Dalam konteks itu sekolah dan guru-guru di TK dan RA khususnya, memerlukan referensi pengembangan tema-tema pembelajaran anak usia dini yang mengangkat nilai-nilai keislaman sesuai dengan perkembangan anak. Berdasarkan kajian penelitian yang sudah dilakukan sebelumnya, menunjukkan bahwa belum adanya program pengembangan pembelajaran yang utuh dan komprehensif dalam melaksanakan proses pembelajaran tematik berbasis nilai-nilai keislaman pada proses pembelajaran di sekolah. Dengan ini, pengembangan program pembelajaran PAUD tematik berbasis nilai-nilai keislaman sangat dibutuhkan sebagai pedoman pelaksanaan pembelajaran di TK/RA sebagai wujud Islam yang rahmatan lil alamin.

Uji pakar atau validasi pakar yang digunakan pada penelitian dan penembangan ini melibatkan pakar di bidang ahli masing-masing, yang terdiri tadi ahli materi Pendidikan anak usia dini, ahli desain pembelajaran serta ahli Bahasa. Validasi pakar atau uji kepakaran yang digunakan dalam penelitian ini melibatkan beberapa ahli yang masing-masing ahli dibidangnya terdiri dari ahli materi anak usia dini, ahli desainpembelajaran, ahli Bahasa. Pada tahapan ini ahli memberikan penilaian dan pandangannya mengenai produk yang sedang dikembangkan dan memberikan saran perbaikan sesuai dengan keahliannya.

Penyusunan materi pembelajaran dalam hal ini silabus pembelajaran TK/RA berbasis nilai-nilai keislaman sudah dibuat dengan menggunakan pengembangan Dick \& Carey dalam pengembangan nilai-nilai keislaman. Pengembangan yang dilakukan telah memuat Tujuan Istruksional Umum dan Istrusksional Khusus yang dirumuskan sesuai dengan kebutuhan dan tahapan perkembangan anak TK/RA, berupaya dengan memilih tema-tema yang relevan bagi anak untuk dipelajari dan diperkenalkan.

Materi yang dikembangakan berdasar pada Al-Quran, Hadis dan literatur keislaman dengan mempertimbangkan konteks kehidupan anak dan lingkungan sekitar, sehingga materi yang diajarkan tidak terlalu jauh dengan anak, melainkan dekat dengan anak. Kebenaran konsep dan pengetahuan yang dijelaskan sesuai dengan konteks keilmuan Pendidikan Anak Usia Dini dan keislaman. Hal itu karena penyususnan materi telah menggunakan sumber-sumber yang relevan, menjawab kebutuhan pembelajaran.

Konsep-konsep dalam materi pembelajaran yang dikembangkan sudah konsisten mulai dari yang termudah hingga tersulit, seperti materi rukun iman dan rukun Islam, shalat, puasa, berbuat baik pada orang tua, berbuat baik pada guru, keluarga dan liungkungan semua dibuat dengan memperhatikan nilai-nilai keislaman yang rahmatan lil alamiin dan humanis, serta holistik integratif. 
DOI: 10.31004/obsesi.v6i1.938

Sebelum melakukan ujicoba, program pembelajaran tematik PAUD berbasis nilai-nilai keislaman yang dikembangkan divalidasi terlebih dahulu oleh ahli materi. Validasi materi dilaksanakan oleh para ahli Pendidikan Anak Usia Dini dan Ahli Pembelajaran yang mempunyai latar belakang sesuai dengan materi yang dikembangkan. Hasil validasi terlihat pada gambar 5.

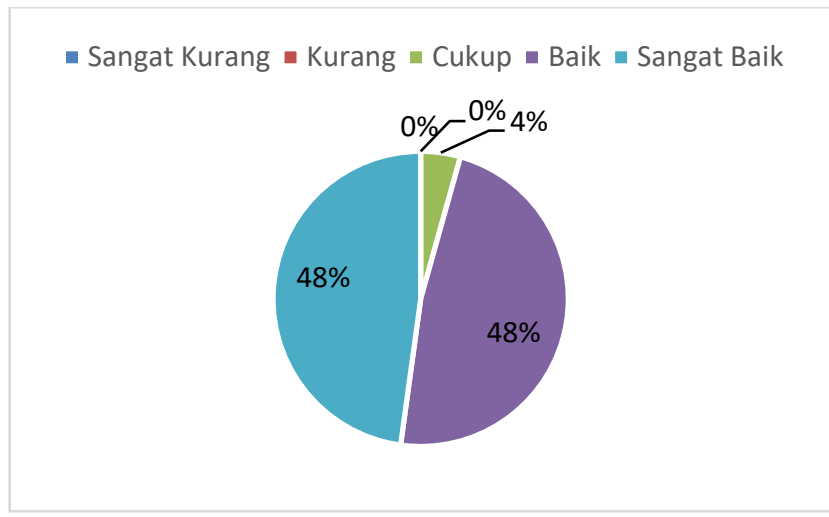

\section{Gambar 5. Grafik Hasil Validasi Ahli Materi}

Hasil penilaian dari ahli/pakar tentang materi PAUD memberikan nilai sebesar 79 dengan persentase $85,8 \%$. Dengan rata-rata skor 3,43 yang masuk kepada kategori baik dari 3 Aspek dan 23 indikator yang dinilai.

Penyusunan pembelajaran yang menggunakan model pembelajaran Dick \& Carey dan diujikan dengan tahapan Borg and Gall menunjukkan bahwa peneliti sangat ingin memberikan kesan pembelajaran yang sistematis dan terstruktur. Pendekatan pembelajaran yang sistematis mengharuskan peneliti untuk merumuskan tujuan yang jelas sesuai dengan analisis kebutuhan dan menghendaki hasil akhir yang maksimal.

Hirarki bahan pembelajaran telah mendukung pencapaian tujuan umum dan tujuan khusus serta masing-masing tujuan indikator kompetensi. Selain itu, semua tema dan sub tema, materi pembelajaran dan langkah-langkah pembelajaran serta kegiatan dan penilaian pembelajaran disusun berdasarkan struktur kurikulum 2013 yang juga disesuaikan dengan sistem pembelajaran secara umum.

Dalam konteks itu, maka guru harus memperhatikan unsur-unsur pembelajaran yang terkandung dalam kurikulum 2013. Dalam hal ini pengembangan pembelajaran yang tematis dan pembelajaran yang berbasis pada keaktifan siswa. Penyajian hasil validasi ahli desain pembelajaran pada gambar 6 .

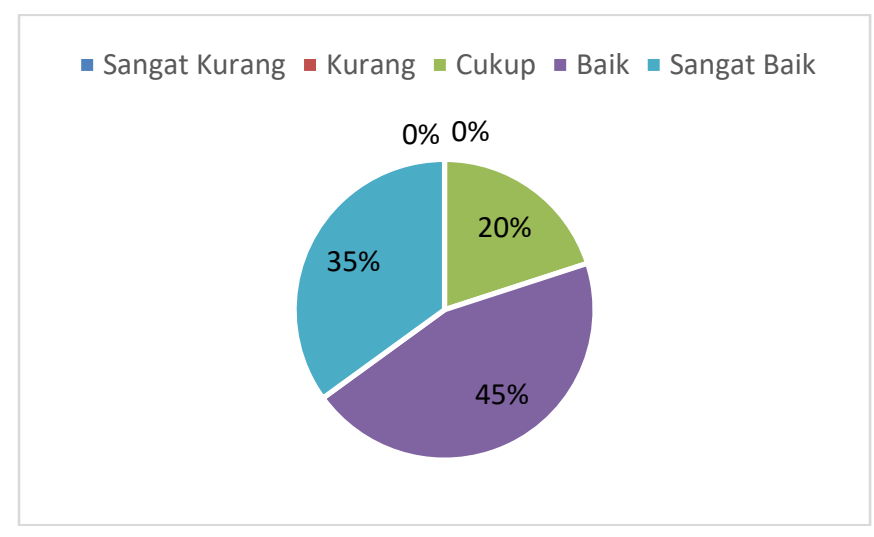

Gambar 6. Grafik Hasil Validasi Ahli Desain Pembelajaran 
Berdasarkan data hasil penilaian ahli desain pembelajaran mendapatkan jumlah skor keseluruhan 83 dari 8 aspek dan 20 indikator yang dinilai. Dapat diinterprestasikan pada kriteria "Baik" dengan tingkat kelayakan "Layak".

Menurut penilaian ahli desain, ukuran buku pedoman pengembangan program pembelajaran dapat memudahkan guru sebagai pengguna dalam mempraktekkan isi dan langkah-langkah pembelajaran yang ada. Tampilan cover sudah mewakili judul buku hanya saja perlu ditambahkan unsur keislaman pada ilustrasinya. Sistematika isi sudah terlihat secara konsisten hanya saja ada beberapa bagian yang perlu diperbaiki lagi terkait penomeran dan ukuran margin serta tabelnya.

Aspek bahasa dalam penyusunan rancangan pembelajaran sangat penting agar pembaca dapat dengan mudah menerima informasi yang termuat. Hal ini memerlukan penggunaan kaidah-kaidah bahasa yang baik dan benar, penyesuaian struktur kalimat dengan pemahaman pembaca, yaitu disesuaikan dengan pemahaman guru atau pengguna buku sehingga tidak merepotkan dan menimbulkan pemahaman yang berbeda dari yang dimaksudkan.

Pemilihan kata sudah disesuaikan dengan kalimat atau kata-kata yang sederhana terutama materi-materi yang membutuhkan pemahaman lanjutan, penyajian bahasa berbelitbelit dan membingungkan harus dihindari, sebaliknya penyajian bahasa yang lugas dan tepat sasaran sangat perlu sehingga pembaca dapat mengerti. Penyajian hasil validasi ahli Bahasa pada gambar 7 .

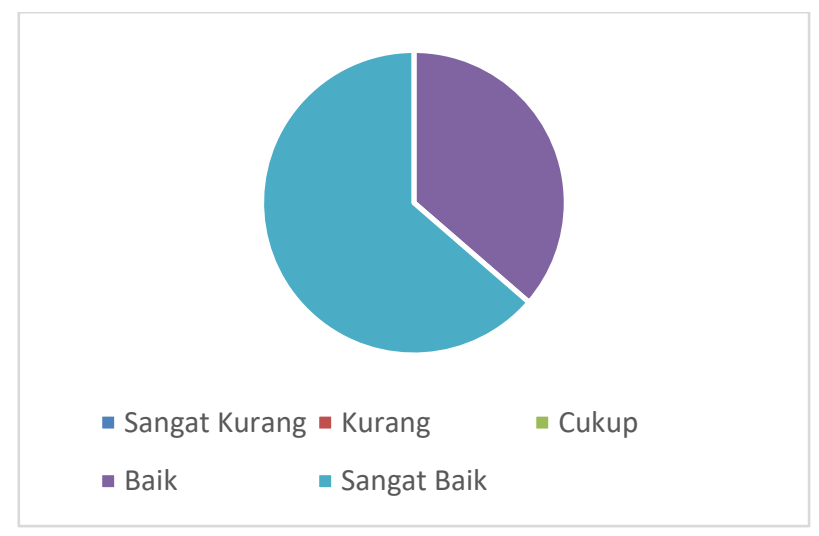

Gambar 7. Grafik Hasil Validasi Ahli Bahasa

Berdasarkan data hasil penilaian ahli bahasa, mendapatkan jumlah skor keseluruhan 40 persentase 90,9\%. Dengan rata-rata skor 3,63 yang masuk pada ketegori baik dari 11 indikator yang dinilai.

\section{Hasil Evaluasi One to One Guru}

Berdasarkan hasil penilaian one to one oleh guru didapati bahwa pengembangan program pembelajaran berdasarkan nilai-nilai keislaman jika dirata-rata maka mendapat penilaian sangat baik terdapat 16 indikator meliputi: Mencantumkan Identitas RPPH, menjelaskan tentang pemilihan tema, kompetensi inti dicantumkan pada RPPH dan dipilih sesuai dengan KD serta indikator, Kompetensi Dasar (KD) dijelaskan dalam RPPH, dicantumkan nomor poin, kemudian disesuaikan dengan aspek perkembangan anak, tujuan dijelaskan sesuai dengan tingkat pencapaian perkembangan anak berdasarkan usia, menjelaskan kegiatan apersepsi di dalam RPPH sebagai stimulasi awal pembelajaran anak, menjelaskan media yang digunakan untuk pembelajaran dalam $\mathrm{RPPH}$, terdapat alokasi waktu dalam setiap kegiatan, mencantumkan materi pembiasaan di kelas, proses saintifik; mengamati, menanya, mengumpulkan informasi, mengasosiasi, mengkomunikasikan, terdapat kegiatan menyampaikan tentang informasi apa saja yang di dapat tentang objek yang 
dipelajari secara lisan, kerapihan dan kebersihan: serta penggunaan kata dalam penulisan $\mathrm{RPPH}$.

Adapun penilaian baik terdapat pada 4 indikator meliputi: indikator dijelaskan dengan kata kerja operasional dan juga berisi tujuan dilaksanakannya pembelajaran, menjelaskan materi kegiatan belajar di dalam RPPH, mencantumkan alat dan bahan untuk kegiatan pembelajaran di dalam RPPH, menjelaskan beberapa jenis penilaian di dalam RPPH.

Berdasarkan hasil penilaian yang telah dilakukan baik uji validasi ahli maupun penilaian one to one guru didapati bahwa pengambangan program pembelajaran berbasis nilai-nilai keislaman telah dapat dilakukan untuk kelompok yang lebih besar. Berdasarkan kajian ahli materi, ahli desain pembelajaran, ahli bahasa memberikan rekomendasi untuk menggunakan program yang telah dikembangakan dalam pembelajaran.

Adapun hasil penilaian one to one guru merekomendasikan pengambangan program pembelajaran berbasis nilai-nilai keislaman sangat baik dengan beberapa catatan masukan perbaikan, diantaranya, penyesuaian dengan pendekatan saintifik yang lebih variatif, penilaian yang beragam, menghilangkan gambar, dan penyesuaian dengan tema pandemi.

Di atas itu semua pengembangan program pembelajaran berbasis nilai-nilai keislaman sudah sangat layak untuk dapat diterapkan. Sementara itu, pengembangan lebih lanjut dibutuhkan untuk menyempurnakan program agar lebih baik lagi dan kontekstual.

Penelitian yang dilakukan oleh Robert H. Bradley, Lorraine M. McKelvey and Leanne Whiteside-Mansell menjelaskan bahwa telah banyak program yang dirancang untuk pembelajaran bagi anak usia dini serta telah dievaluasi, ternyata tidak semua intervensi dan program yang dikembangkan dapat berjalan secara baik dan efektif untuk anak. Kualitas program tidak ditentukan oleh banyaknya intervensi yang dilakukan, tidak berarti semakin banyak program atau intervensi yang diberikan akan memberikan pengaruh yang positif juga pada anak atau sebaliknya (Bradley et al., 2011).

Kurikulum terdiri dari pengetahuan dan keterampilan yang akan diperoleh dalam program pendidikan serta rencana untuk membangun pengalaman melalui pembelajaran yang berlangsung (NAEYC, 2009). Kurikulum, pengetahuan dan keterampilan diharapkan untuk diajarkan guru dan membuat anak-anak belajar, serta membuat rencana untuk membangun pengalaman melalui pembelajaran yang akan berlangsung (Epstein, 2007).

Salah satu konsep kurikulum sistematis yang paling awal diciptakan oleh Johann Heinrich Pestalozzi, sekolahnya dibuat untuk kelompok usia campuran di Yverdon, Swiss (didirikan 1805). Pandangan Pestalozzi dipengaruhi oleh Plato dan Rousseau yang menyebutkan bahwa anak akan berkembang dengan baik secara alami dari waktu ke waktu, Pestalozzi menciptakan doktrin Anschauung (langsung dan pengamatan konkret), dan memanfaatkan spontanitas anak dan orang dewasa serta aktivitas peer-guided, kelompok terbimbing (Weber, 1984).

Melalui objek pembelajaran yang mendorong anak-anak untuk mengamati dan mengeksplorasi benda-benda yang dikumpulkan dari lingkungan natural, kurikulum Pestalozzi berupaya mengenalkan anak-anak akan bentuk, bahasa, dan klasifikasi angka dan mendorong anak-anak untuk mengembangkan kekuatan mereka sendiri dalam melihat, menilai, dan bemalar (Heafford, 2016). Prinsip kurikuler yang mendasari adalah untuk memperkenalkan konsep abstrak melalui benda-benda konkret, selalu berkembang secara individual dan kumulatif dari konsep yang lebih mudah ke yang lebih sulit.

Pada tahun 1980-an, perdebatan besar lainnya terjadi di bidang pendidikan anak usia dini. Melalui National Association of the Education of Young Children (NAEYC), para ahli pendidikan menerbitkan pedoman praktik pembelajaran yang sesuai dengan perkembangan (DAP) pada tahun 1986 (Bredekamp \& Copple, 1997) (disempurnakan pada tahun 1987) melakukan standarisasi dari pelaksanaan praktek pembelajaran anak yang beragam (e. g., nursery schools child care, Head Start, dan kindergartens), panduan ini terbukti berhasil menjadi alat yang sangat dibutuhkan untuk menyediakan layanan berkualitas tinggi bagi anak-anak dan keluarga. Ini didukung oleh beberapa studi longitudinal yang memverifikasi 
hasil positif dan manfaat program pembelajaran seperti High Scope, Regio Emilia dan Montessori sebagai kurikulum yang berorientasi perkembangan. Dukungan ilmiah semacam itu menarik perhatian para pembuat kebijakan. Konsep DAP menjadi trend yang akhirnya disusun dari beberapa pendekatan pembelajaran langsung di kelas awal. Panduan DAP direvisi satu dekade setelah publikasi pertama untuk mengakomodasi perspektif sosiokultutral yang lebih baru dalam teori perkembangan (Lim \& Genishi, 2010).

Program pembelajaran diberikan sebagai intervensi untuk anak usia dini dalam mengembangkan seluruh aspek perkembangannya. Program ini dikembangkan dengan landasan yang dibangun dari teori-teori program pembelajaran yang diintegrasikan dengan teori-teori perkembangan anak. Program pendidikan anak usia dini juga memerhatikan: tujuan, efektivitas, waktu, penargetan, dan konten yang optimal; serta biaya dan manfaat. intervensi dini memiliki manfaat jangka pendek dan jangka menengah yang signifikan: yang paling utama adalah mengurangi pengulangan, biaya pendidikan khusus dan menyediakan pengasuhan anak yang berkualitas (Hernandez et al., 2016).

Berdasarkan kajian teori-teori di atas program pembelajaran adalah sebuah program yang meliputi proses pembelajaran dengan rancangan yang terorganisir sistematis dengan memperharikan aspek-aspek pembelajaran anak usia dini dan juga aspek-aspek pengembangan pembelajaran secara umum. Yaitu dengan menentukan tujuan, keadaan peserta didik, materi pembelajaran, media pembelajaran. strategi pembelajaran dan juga evaluasi.

Pendidikan anak usia dini (PAUD) adalah pendidikan yang paling utama dalam proses kehidupan diri seorang manusia dalam menentukan fase-fase kehidupan berikutnya. PAUD kemudian menjadi pendidikan yang diperhatikan secara serius oleh pemerhati dan pengkaji pendidikan secara internasional. Berdasar pemahaman itu, maka PAUD di lndonesia secara masif diperhatikan dalam seluruh wilayah Indonesia. Sebagai negara kepulauan Indonesia memiliki beraneka ragam suku, ras, dan budaya yang harus disesuaikan dengan pengembangan PAUD.

Pembelajaran yang memungkinkan kesesuaian dengan tahapan perkembangan anak dan mengakomodir pemenuhan kebutuhan belajar anak dapat dilakukan dengan pembelajaran tematik. Pembelajaran tematik dianggap sesuai dengan cara kerja otak manusia yang berusaha untuk membahas satu tema dengan pendekatan berbagai konsep dan aspek perkembangan anak. Pemelihan tema sangat fleksibel, sesuai dengan kebutuhan pembelajaran di PAUD disesuaikan dengan kebutuhan, minat, kesukaan, kemenarikan, lingkungan sosial dan kesederahanaan sebuah tema pembelajaran dan kesiapan guru dalam melakukan kegiatan pembelajaran (Kemdikbud, 2018).

Tema menjadi payung untuk mengkolaborasikan dan mengintegrasikan konsep dan muatan kurikulum melalui kegiatan yang menarik untuk mencapai tujuan/kompetensi pembelajaran yang sesuai dengan tingkat perkembangan (Kemdikbud, 2018) Menurut Fogarty (1991) ada sepuluh cara untuk mengintegrasikan konsep-konsep dalam pembelajaran; (1) connected, (2) nested, (3) fragmented, (4) shared, (5) webbed, (6) sequenced, (7) networked, (8) threaded, (9) immersed, dan (10) integrated. Dari sepuluh model yang dikembangkan maka peneliti menggunakan model tematik webbed. Model webbed (jarring laba-laba) merupakan pembelajaran tematik yang dimulai dengan menentukan tema tertentu. Tema bisa diperoleh dari hasil musyawarah/dialog dengan anak, dan bisa didapat dari hasil diskusi dengan sesama guru. Setelah ditentukan temanya, maka untuk langkah selanjutnya adalah menentukan sub tema dan sub-sub tema dari tema tersebut dengan memperhatikan kaitannya dengan materi pembelajaran serta kompetensi yang ingin dicapai. Dari sub tema tersebut dikembangkan aktivitas/kegiatan belajar yang bisa dilakukan anak (Fogarty, 1991).

Fogarty menyatakan bahwa karakteristik model model jaring laba-laba (webbed) adalah adanya pandangan luas secara keseluruhan dalam suatu tema yang dapat membentuk jaringan dari berbagai bidang pengembangan. Model webbed, dalam penerapannya melalui tahapan-tahapan agar penyajian informasi berjalan sebagaimana mestinya. Langkah-langkah 
pembelajaran tema model webbed yaitu: (1) menganalisis KI-KD pembelajaran di TK/RA; (2) menentukan tema pembelajaran; (3) mengidentifikasi tema dan sub tema dan memetakkannya dalam jaringan tema; (4) merumuskan indikator pada setiap kompetensi melalui tema dan subtema; (5) dari tema yang telah ditentukan anak akan mendapatkan konsep pengetahuan baru yang berkaitan dengan tema; (6) anak diminta agar mengembangkan konsep tersebut dengan pengetahuan baru.

Pembelajaran tematik lebih menekankan pada keterlibatan anak dalam proses belajar secara aktif dalam proses pembelajaran, sehingga anak dapat memperoleh pengalaman langsung dan terlatih untuk dapat menemukan sendiri berbagai pengetahuan yang dipelajarinya. Melalui pengalaman langsung anak akan memahami konsep-konsep yang dipelajari dan menghubungkannya dengan konsep lain yang telah dipahaminya. Teori pembelajaran ini dimotori para tokoh Psikologi Gestalt, termasuk Piaget yang menekankan bahwa pembelajaran haruslah bermakna dan berorientasi pada kebutuhan dan perkembangan anak. Pembelajaran tematik lebih menekankan pada penerapan konsep belajar sambil melakukan sesuatu (learning by doing).

Oleh karena itu, guru perlu mengemas atau merancang pengalaman belajar yang akan mempengaruhi kebermaknaan belajar anak. Pengalaman belajar yang menunjukkan kaitan unsur-unsur konseptual menjadikan proses pembelajaran lebih efektif. Kaitan konseptual antar sub-tema yang dipelajari akan membentuk skema, sehingga anak akan memperoleh keutuhan dan kebulatan pengetahuan. Selain itu, dengan penerapan pembelajaran tematik di membantu anak belajar sesuai denga perkembangannya.

Sebagai suatu model pembelajaran, pembelajaran tematik memiliki karakteristikkarakteristik sebagai berikut: (1) berpusat pada anak (2) memberikan pengalaman langsung, dengan pengalaman langsung ini, siswa dihadapkan pada sesuatu yang nyata (konkrit) sebagai dasar untuk memahami hal-hal yang lebih abstrak. (3) fokus pembelajaran diarahkan kepada pembahasan tema-tema yang paling dekat berkaitan dengan kehidupan anak (4) menyajikan konsep dari berbagai aspek perkembangan (5) bersifat fleksibel dimana guru dapat mengaitkan bahan ajar dari sub-tema ke sub-tema lainnya dan mengaitkannya dengan kehidupan dan lingkungan anak (6) belajar sesuai dengan minat dan kebutuhan anak, dimana anak diberi kesempatan untuk mengoptimalkan potensi yang dimilikinya sesuai dengan minat dan kebutuhannya (7) menggunakan prinsip belajar sambil bermain dan menyenangkan.

Bentuk program pembelajaran yang disusun berupa buku teks, yaitu buku yang digunakan dalam proses kegiatan pembelajaran berbasis nilai-nilai keislaman, yang disusun dengan menggunakan langkah-langkah model pengembangan sehingga sejalan dengan prinsip-prinsip belajar dan pembelajaran. Program pembelajaran disusun berdasarkan pendekatan tematik/konstruktivistik dengan strategi pembelajaran yang disesuaikan dengan pendidikan anak usia dini.

Nilai-nilai Islam adalah nilai-nilai yang terkandung dalam Al-Quran. Nilai-nilai Islam dalam Al-Quran tersebar dalam huruf dan ayat-ayat Al-Quran. Setiap nilai yang terkandung dalam Al-Qur'an memiliki pelajaran yang bermakna dalam menumbuhkan iman, kemanusiaan dan moralitas (Hayati, 2018). Nilai-nilai Islam adalah prinsip yang perlu ditanamkan sejak dini. Penanaman nilai-nilai Islam sejak usia dini akan menghasilkan anakanak yang memiliki wawasan moderat dan memiliki karakter yang baik. Agama adalah fondasi pertama dan terpenting dalam mengembangkan pendidikan karakter di Indonesia, terutama pada institusi PAUD (Fadlillah \& Khorida, 2013)

Anak yang diberikan pembelajaran nilai keislaman diharapkan menjadi insan kamil (manusia ideal). Manusia yang berpendidikan baik lahir batin sehingga dapat dengan totalitas berhubungan dengan Tuhan dan dengan manusia sesuai dengan ketentuan akhlak yang benar. Dengan adanya pendidikan akhlak, seorang anak dapat memahami tata krama yang benar dalam menjalani kehidupan ini sesuai dengan situasi dan kondisi dimana dirinya berada (Witro, 2019). 
Nilai-nilai keislaman yang diambil dari nilai-nilai Al-Quran dan Hadis adalah sebagai berikut: takut kepada Allah, kewajiban melakukan shalat dan melaksanakannya dengan sempurna, menghindari dosa, bersabar atas apa yang terjadi dan menghindari kesombongan. Guru dapat menjelaskan tentang; (1) Keyakinan (iman) kepada Allah dengan tauhid murni dan menghindari syirik (2) Kebaikan, hormat dan kepatuhan terhadap orang tua (3) Takut akan Allah dan kesadaran akan kehadiran-Nya (4) Berdoa dengan cara yang benar (5) Mengerjakan kebaikan dan meninggalkan keburukan (6) Menjalani hidup dengan sabar (7) Kerendahan hati dan kelembutan (8) Moderasi dan penghindaran yang ekstrim (9) Kekuatan dalam keyakinan (10) Tanggung jawab menjadi orang tua (11) Keterikatan pada Al-Qur'an dan hadits otentik (12) Cinta dan ketulusan kepada Allah, Rasul-Nya, dan Kitab-Nya (12) Kepatuhan pada Sunnah Nabi (13) Memahami segala sesuatu dari perspektif Islam (14) Kepribadian, nilai, dan identitas Islam (15) Kesetaraan dan keadilan dalam berurusan dengan orang lain (16) Kebanggaan menjadi Muslim.

Nilai-nilai keislaman ini diimplementasikan dalam pembelajaran dalam bentuk kegiatan mempraktekkan pemahaman tentang rukun iman dan rukun Islam, shalat fardu dan shalat sunah, terbiasa bersyukur dengan mengucapkan lafaz hamadalah, melafazkan suratsurat pendek, peringatan hari besar Islam, terbiasa berdoa, cerita para nabi, berbuat baik kepada diri sendiri, teman, orangtua, guru dan lingkungan, story telling kisah-kisah teladan, role play tentang tema keislaman seperti tanggung jawab, toleransi dan saling menyayangi melalui kegiatan jual beli. Pemahamanan terhadap tema nilai-nilai Islam sangat mungkin untuk memunculkan banyak tema yang bisa disarikan dari Al Qur'an dan Hadis, hal ini dapat dieksplorasi untuk pembelajaran anak usia dini. Begitu juga, dalam pemilihan alat permainan dalam pembelajaran yang dikembangkan menjadi sangat kaya akan nilai.

\section{SIMPULAN}

Pengembangan program pembelajaran berbasis nilai-nilai keislaman layak untuk diterapkan dalam pembelajaran PAUD, khususnya di TK berbasis Islam dan Raudhatul Athfal. Kebaruan penelitian ini adalah menjadi pedoman pengembangan pembelajaran dengan tema keislaman yang menjiwai ruh kegiatan pembelajaran di sekolah. Namun demikian, pengembangan pembelajaran dengan nilai keislaman ini harus ditelaah lebih dalam lagi, sehingga manfaatnya bisa dirasakan. Dalam artian, setiap kegiatan perlu diselaraskan dengan temuan ilmiah serta kontekstualisasi dengan nilai psikologis dalam hal ini psikologi perkembangn anak, kesehatan, ekonomi dan spiritualitas. Sehingga yang dilakukan sudah teruji dan terus menemukan hikmah serta relevansinya dalam menjawab tantangan zaman (sholihun li kulli makan wa zaman).

\section{UCAPAN TERIMA KASIH}

Penelitian ini terlaksana dengan baik karena bantuan dari berbagai pihak, untuk itu ucapan terimakasih disampaikan kepada semua pihak; Direktorat Pendidikan Tinggi Keagamaan Islam bidang Penelitian, Publikasi Ilmiah dan Pengabdian Masyarakat (litapdimas), Pusat Penelitian dan Penerbitan (Puslitpen), LP2M UIN Syarif Hidayatullah Jakarta, civitas akademika program studi Pendidikan Islam Anak Usia Dini UIN Syarif Hidayatullah dan PG-PAUD STKIP Kusuma Negara Jakarta, pakar penilai (ahli PAUD, Bahasa dan Teknologi Pembelajaran) serta guru-guru TK dan RA di Ciputat.

\section{DAFTAR PUSTAKA}

Black, M. M., Walker, S. P., Fernald, L. C. H., Andersen, C. T., DiGirolamo, A. M., Lu, C., McCoy, D. C., Fink, G., Shawar, Y. R., Shiffman, J., Devercelli, A. E., Wodon, Q. T., Vargas-Barón, E., \& Grantham-McGregor, S. (2017). Early childhood development coming of age: science through the life course. In The Lancet (Vol. 389, Issue 10064, pp. 77-90). Elsevier. https://doi.org/10.1016/S0140-6736(16)31389-7 
DOI: 10.31004/obsesi.v6i1.938

Bradley, R. H., Mckelvey, L. M., \& Whiteside-Mansell, L. (2011). Does the Quality of Stimulation and Support in the Home Environment Moderate the Effect of Early Education Programs? Child Development, 82(6), 2110-2122. https://doi.org/10.1111/j.1467-8624.2011.01659.x

Bredekamp, S., \& Copple, C. (1997). Developmentally appropriate practice in early childhood programs (rev. edn). ERIC.

Britto, P. R., Singh, M., Dua, T., Kaur, R., \& Yousafzai, A. K. (2018). What implementation evidence matters: Scaling-up nurturing interventions that promote early childhood development. Annals of the New York Academy of Sciences, 1419(1), 5-16. https://doi.org/10.1111/nyas.13720

Bruce, T. (2012). Early childhood practice: Froebel today. In Early Childhood Practice: Froebel Today. Sage. https:// doi.org/10.4135/9781446251287

Cahan, E. D. (1992). John Dewey and Human Development. Developmental Psychology, 28(2), 205-214. https:// doi.org/10.1037/0012-1649.28.2.205

Daelmans, B., Darmstadt, G. L., Lombardi, J., Black, M. M., Britto, P. R., Lye, S., Dua, T., Bhutta, Z. A., \& Richter, L. M. (2017). Early childhood development: the foundation of sustainable development. In The Lancet (Vol. 389, Issue 10064, pp. 9-11). Elsevier. https://doi.org/10.1016/S0140-6736(16)31659-2

Dick, W., Carey, L., \& Carey, J. O. (2005). The systematic design of instruction.

Endang, B. (2012). Futurologi dan Phenomenologi Nilai Spritual ( Hubungan Allah, Manusia dan Alam). Jurnal Visi Ilmu Pendidikan, 2(1). https:// doi.org/10.26418/jvip.v2i1.366

Epstein, A. (2007). The intentional teacher. Exchange, 734-742.

Fadlillah, M., \& Khorida, L. M. (2013). Pendidikan karakter anak usia dini. Jogjakarta: Ar-Ruzz Media, 25.

Fogarty, R. (1991). How to integrate the curricula. Skylight, October, 1-21. https://doi.org/10.1007/978-1-4419-9688-6_1

Gall, M. D., Borg, W. R., \& Gall, J. P. (1996). Educational research: An introduction, 6th ed. In Longman Publishing (Vol. 6).

Hayati, M. (2018). Designing of Educational Game Tools for Early Childhood Development Based on Islamic Values. International Conference on Education in Muslim Society (ICEMS 2017). https://doi.org/10.2991/icems-17.2018.38

Heafford, M. R. (2016). Pestalozzi: His thought and its relevance today. In Pestalozzi: His Thought and its Relevance Today. Routledge. https:// doi.org/10.4324/9781315441405

Hernandez, D. J., Denton, N. A., \& Macartney, S. (2016). Early Childhood Education Programs. In The Next Generation (pp. 46-66). https://doi.org/10.18574/nyu/9780814707425.003.0003

Ikhwan, A., Biantoro, O. F., \& Rohmad, A. (2019). The Role of the Family in Internalizing Islamic Values. Dinamika Ilmu, 19(2), 323. https:// doi.org/10.21093/di.v19i2.1746

Jasuri, J. (2015). Pembelajaran Pendidikan Agama Islam pada Anak Usia Dini. Madaniyah, 5(1), 195070. https://doi.org/10.22373/je.v1i2.605

Joni. (2009). Pembelajaran Tematik pada Pendidikan Anak Usia Dini. Jurnal At-Ta'dib, 4(1), 35-49.

Kemdikbud. (2018). Pengembangan tema pembelajaran. 021.

Lim, S. M. Y., \& Genishi, C. (2010). Early childhood curriculum and developmental theory. In International Encyclopedia of Education (pp. 514-519). https:// doi.org/10.1016/B9780-08-044894-7.00087-7

Mathwasa, J., \& Okeke, C. I. O. (2017). Mothers' perceptions on Fathers' participation in the early childhood education of their children. Journal of Social Sciences, 51(1-3), 29-41. https://doi.org/10.1080/09718923.2017.1305576

NAEYC. (2009). NAEYC Standards for Early Childhood Professional Preparation Programs. In Position statement. NAEYC Washington, DC. 
Nasution, A. (2018). Sekularitas Dan Spritualitas: Mencari Format Integrasi Ilmu Untuk Konstruksi Kurikulum Pendidikan Islam. Jurnal Tarbiyah, 25(1). https:// doi.org/10.30829/tar.v25i1.243

Powell, D. R., \& Dunn, L. A. (1990). Non-baccalaureate teacher education in early childhood education. Journal of Early Childhood Teacher Education, 11(1), 3. https:// doi.org/10.1080/10901027.1990.11089908

Santrock, J. W. (2002). Life-span development.

Schnepp, G. J., \& Hurlock, E. B. (1950). Child Growth and Development. The American Catholic Sociological Review, 11(2), 104. https:/ / doi.org/10.2307/3707488

Sidiq, U., \& Ikhwan, A. (2018). Local Government Policy Regarding Mandatory Students Diniyah Takmiliyah in Indramayu Regency. KARSA: Journal of Social and Islamic Culture, 26(1), 70. https:// doi.org/10.19105/karsa.v26i1.1444

Suryana, D. (2016). Pendidikan Anak Usia Dini: Stimulasi \& Aspek Perkembangan Anak. Prenada Media.

Thornton, L., \& Brunton, P. (2014). Bringing the Reggio approach to your early years practice. In Bringing the Reggio Approach to your Early Years Practice. Routledge. https://doi.org/10.4324/9780203935378

Weber, E. (1984). Ideas influencing early childhood education : a theoretical analysis. In Early childhood education series. Teachers College Press.

Witro, D. (2019). Islamic Religious Education in the Family to Strengthen National Resilience of Surah At-Tahrim Verse 6 Perspective. Al-Muaddib: Jurnal Ilmu-Ilmu Sosial Dan Keislaman, 4(2), 306-315.

Yani, A., \& Jazariyah, J. (2020). Penyelenggaraan PAUD Berbasis Karakter Kebhinekaan sebagai Upaya Pencegahan Radikalisme Sejak Dini. Jurnal Obsesi : Jurnal Pendidikan Anak Usia Dini, 5(1), 1. https://doi.org/10.31004/obsesi.v5i1.503 